\title{
The Effect of the Bank Indonesia Interest Rate, Exchange Rate, and Bond Rating against Bond Yield: Registered Corporate Bonds Issuing Company on the Indonesia Stock Exchange
}

\author{
Andini Nurwulandari \\ Universitas Nasional, Jakarta \\ Email: andinmanajemen@gmail.com
}

\begin{abstract}
In the current development of the world economic system, movements in the financial system that occur in the world are also affected. Judging from the development of the financial system, it is inseparable from banking, which is an absolute part of it. This condition was reflected in the state of Indonesia during the economic and monetary crisis. This research is a quantitative study with a descriptive analysis approach. The data source is in the form of secondary data obtained from the BEI IBMD 2017-2020. The documentation technique is the data collection technique in this research. All corporate bond issuers listed on the IDx for the 2017-2020 period are the population used in this study. The collection of the samples uses a deliberate sample. In this study the analysis utilizes the determination coefficient, multiple analyzes for linear regression and self-relation. From the above results of discussion and analysis, we can conclude that: 1) the BI rate variable in Indonesia affects bond returns positively and in a significant way in corporate-bond issuing companies; 2) the BT variable affects bond yields in corporate-binding companies; and 3) the BTV has a negative and meaningful effect on bond yields in corporated-bond issuing companies.
\end{abstract}

Keyword: BI Rate, Exchange Rate, Bond Rating, Bond Yield.

\section{A. INTRODUCTION}

The magnitude of the interest rate (BI Rate) is one factor for banks to determine the number of interest rates offered to the public. Interest rates affect the desire and interest of the people to invest their funds in the bank through the products offered (Eichengreen \& Hausmann, 1999). The impact on the bank itself, namely the increasing number of funds invested by the public, will increase the bank's ability to channel these funds in the form of credit wherefrom the credit channeled, the bank gets a profit (Ferguson \& Schularick, 2007). Thus, the more loans are distributed, the impact on the amount of income that the bank earns.

Unreasonable interest rate developments can directly disrupt banking developments (Fidora, Fratzscher \& Thimann, 2007). On the one hand, high interest rates will increase people's desire to save to raise banking funds (Gadanecz, Miyajima \& Shu, 2018). The interest rate is a measure of how much it costs or revenues in connection with the use of money for a certain period. On the banking side, with high interest rates, banks will raise funds to distribute credit to the business world (Gupta, Chevalier \& Sayekt, 2001). 
The BI Rate is an interest rate with a tenor of one month announced by Bank Indonesia periodically, which serves as a signal (stance) for monetary policy (Hasanudin \& Awaloedin, 2020). In simple terms, the BI Rate indicates the shortterm interest rate desired by Bank Indonesia in its efforts to achieve the inflation target (Hasanudin, 2021).

The establishment of the BI rate usually takes effect during the current quarter at the quarterly meeting of the Board of Directors (January, April, July and October) by taking into account the recommendations for the BI rate generated in the policy reaction role of the Economic Model to achieve the inflation target. In the monthly RDG, too, changes may be made in the BI rate. Changes in the BI rate are made in many 25 basis points (the currency situation can change 25.50 or 75 basis points).

The movement of the rupiah exchange rate against the US dollar after the implementation of the free-floating exchange rate system policy in Indonesia on August 14, 1998, has had an impact on the development of the national economy in both the monetary and real sectors. The depreciation of the rupiah exchange rate against the US dollar became very large at the beginning of implementing the system (Nurwulandari \& Adnyana, 2019).

This has resulted in an increasing degree of uncertainty in business and economic activities in Indonesia. Many factors, both non-economic and financial, are accused of being the cause of the fluctuation in the exchange rate (Nurwulandari, Hasanudin \& Melati, 2021). Non-economic factors are more often seen as the cause of changes in the rupiah exchange rate against the dollar. To prove, even measure how much the non-economic influence will be tough to do (Obstfeld, Shambaugh \& Taylor, 2005). This situation is different from the existence of economic factors, which include inflation, interest rates, money supply, national income, and the position of the international balance of payments, which are generally relatively more measurable (Saenong, Adam, Wali \& Millia, 2020).

Bonds are securities or certificates containing a contract between the lender (investor) and the one given the loan (the issuer). An investor who wants to buy bonds should be careful about bond ratings. The credit rating is a risk scale for all traded bonds. This bond rating is critical because it provides an input and indicates the likelihood of a company's bankruptcy (Wahyudi \& Pangestuti, 2017).

Bond rating agencies are independent agencies which provide rating information on bond risk scales to show how safe a bond is for investors. The ability to pay interest and pay the principal on loans is shown to demonstrate this security. Investors can utilize the rating agencies' services to obtain bond rating information (Wahyudi, Hasanudin \& Pangestutia, 2020).

Bonds are long-term transferable debt securities containing the bond issuer's promise to repay compensation in the form of a fixed period of interest and repay the bond to the purchaser at a specified time (Yusuf \& Prasetyo, 2019). Two sides, namely the issuer and the investor side, can view the issuance of bonds. As far as the issuer is concerned, the bond issuance is relatively cheaper than bank loans or loans. Bond issuance is a secure alternative for investors because bonds provide fixed 
income in the form of interest coupons paid regularly at a competitive interest rate and the main debt payable on time at a predetermined maturity.

Bond income is the key factor for investors to consider as investment instruments when buying bonds. Investors will calculate the investment revenue from funds acquired by means of a yield measures tool for these bonds.

\section{B. METHOD}

This research is a quantitative study with a descriptive analysis approach. The data source is in the form of secondary data obtained from the BEI IBMD 2017-2020. The documentation technique is the data collection technique in this research. All corporate bond issuers listed on IDX during the 2017-2020 period are the population in this study. The sample collection uses purposive sampling. The analysis in this study uses the coefficient of determination, multiple linear regression analysis, and autocorrelation test.

\section{RESULT AND DISCUSSION}

\section{Description of Research Object}

In this study, the sample used is corporate bond issuing companies listed on the IDX, rated by PT. Petfinder for the period 2017-2020. As many as 25 samples of corporate bonds from 14 companies issuing corporate bonds are as follows:

Table 1 Research Samples

\begin{tabular}{|c|l|c|}
\hline No. & \multicolumn{1}{|c|}{ Bonds } & Code \\
\hline 1 & The Obligation of PLN VIII Year 2017 A & PPLN08A \\
\hline 2 & The Obligation of PLN VIII Year 2017 B & PPLN08B \\
\hline 3 & The Obligation of PLN X Year 2020 A & PPLN10A \\
\hline 4 & The Obligation of XI Perum Pegadaian A & PPGD11A \\
\hline 5 & The Obligation of XI Perum Pegadaian A & PPGD12A \\
\hline 6 & The Obligation of Jasa Marga XII Q & JMPD12Q \\
\hline 7 & The Obligation of Jasa Marga XIII R & JMPD13R \\
\hline 8 & The Obligation of Indosat V A & ISAT05A \\
\hline 9 & The Obligation of Indosat V B & ISAT05B \\
\hline 10 & The Obligation of Indosat VI B & ISAT06B \\
\hline 11 & The Obligation of Indosat VII B & ISAT07B \\
\hline 12 & The Obligation of Bank Panin II C & PNBN02C \\
\hline 13 & The Obligation of Bank Panin III & PNBN04 \\
\hline 14 & The Obligation of XII Bank BTN & BBTN12 \\
\hline 15 & Obligation of Indofood Sukses Makmur V & INDF05 \\
\hline 16 & Obligation of Apexindo Pratama Duta II B & MEDC02B \\
\hline 17 & The Obligation of Medco Energi Internasional II B & PPKT02 \\
\hline 18 & The Obligation of Pupuk Kaltim II & SIMP01 \\
\hline 19 & The Obligation of Matahari Putra Prima III B & \\
\hline 20 & The Obligation of Salim Ivomas Pratama I & \\
\hline
\end{tabular}




\begin{tabular}{|c|l|c|}
\hline 21 & The Obligation of Mitra Adiperkasa I B & MAPI01B \\
\hline 22 & The Obligation of VI Bank Jabar Banten B & BJBR06B \\
\hline 23 & The Obligation of XIII Perum Pegadaian A1 & PPGD13A1 \\
\hline 24 & The Obligation of XIII Perum Pegadaian B & PPGD13B \\
\hline 25 & The Obligation of XIII Perum Pegadaian C & PPGD13C \\
\hline
\end{tabular}

Source: Processed data

\section{Descriptive Statistical Analysis}

In this study, the object of research is the yield obligation of the company issuing Obligations of corporations. Yield Obligation is the profit from the Obligation investment that the investor receives. Following are the results of descriptive statistics that describe the yield obligation as follows:

Table 2 Yield Descriptive Statistics

Descriptive Statistics

\begin{tabular}{|l|c|c|c|c|c|}
\hline & $\mathrm{N}$ & Minimum & Maximum & Mean & Std. Deviation \\
\hline Yield & 100 & 6.7493 & 15.7811 & 9.475463 & 1.7957961 \\
Valid N (listwise) & 100 & & & & \\
\hline
\end{tabular}

Source: Processed data

Based on the data processing results with 100 observations from 25 samples of Obligation of corporations for four years, namely the 2017 to 2020 period. $7811 \%$. The average (mean) yield value is 9.475463 , and the standard deviation is 1.7957961 .

Table 3 Yield Obligation of 2017-2020 Period (in\%)

\begin{tabular}{|c|c|c|c|c|}
\hline \multirow{2}{*}{ Code } & \multicolumn{4}{|c|}{ Year } \\
\cline { 2 - 5 } & $\mathbf{2 0 1 7}$ & $\mathbf{2 0 1 8}$ & $\mathbf{2 0 1 9}$ & $\mathbf{2 0 2 0}$ \\
\hline PPLN17A & 12.4939 & 9.5407 & 8.4921 & 7.1708 \\
\hline PPLN17B & 14.7812 & 11.4657 & 9.3471 & 8.4424 \\
\hline PPLN20A & 13.5988 & 11.7797 & 7.9364 & 6.9540 \\
\hline PPGD20A & 13.2841 & 9.3014 & 8.7536 & 7.9187 \\
\hline PPGD19A & 11.9310 & 8.8968 & 8.3595 & 7.8150 \\
\hline JMPD20Q & 14.2033 & 9.6814 & 8.4868 & 7.8640 \\
\hline JMPD18R & 12.1929 & 8.9879 & 8.8340 & 7.3516 \\
\hline ISAT18A & 11.7095 & 8.5760 & 7.8046 & 7.1738 \\
\hline ISAT18B & 12.1346 & 8.8134 & 8.5891 & 6.8515 \\
\hline ISAT18B & 12.5973 & 9.2235 & 8.3432 & 9.4664 \\
\hline ISAT19B & 12.7499 & 8.7402 & 8.4234 & 7.6389 \\
\hline PNBN20C & 11.9235 & 11.5293 & 8.5891 & 7.4846 \\
\hline PNBN18 & 12.4556 & 9.4529 & 8.3083 & 12.1812 \\
\hline BBTN17 & 12.1435 & 11.9817 & 8.3160 & 7.5570 \\
\hline INDF19 & 12.2636 & 11.4849 & 7.4462 & 7.3896 \\
\hline APEX18B & 15.7811 & 12.5267 & 12.5915 & 8.1670 \\
\hline MEDC20B & 14.0890 & 9.8943 & 9.3016 & 8.3127 \\
\hline & & & &
\end{tabular}




\begin{tabular}{|c|c|c|c|c|}
\hline PPKT17 & 11.7849 & 9.4616 & 8.6678 & 7.0756 \\
\hline MPPA17B & 13.0420 & 9.8341 & 8.5828 & 7.6439 \\
\hline SIMP018 & 12.6748 & 9.1693 & 9.5815 & 7.7623 \\
\hline MAPI18B & 13.5920 & 11.3270 & 8.7786 & 7.8662 \\
\hline BJBR19B & 12.2789 & 9.7604 & 8.4287 & 7.6637 \\
\hline PPGD19A1 & 12.1022 & 8.8201 & 7.9304 & 6.7492 \\
\hline PPGD17B & 12.8210 & 9.6849 & 7.9989 & 7.8073 \\
\hline PPGD18C & 14.3326 & 9.9039 & 8.8105 & 8.1274 \\
\hline
\end{tabular}

Source: IBPA (Processed Data)

Based on table 3 above, in 2017, the highest yield was $14.7812 \%$, namely the result on Obligation of PLN VIII Year 2017 Series B (PPLN17B), while the lowest outcome was $8.5760 \%$, namely the yield on Obligation of Indosat V Year 2018 Series A (ISAT18A). In 2020, the highest yield was 8,4424\%, namely the yield on Obligation of PLN X Year 2020 Series B (PPLN20B), while the lowest yield was 7,8150\%, namely the yield on Obligation of XIII Perum Pegadaian Year 2019 Series A1 (PPGD19A1).

In 2019, the highest yield was $12.5915 \%$, namely the yield on Obligation of Apexindo Pratama Duta II Year 2018 Series B (APEX18B), while the lowest yield was $7.5462 \%$, namely the yield on Obligation of Indofood Sukses Makmur V 2019 (INDF19). In 2019, the highest yield was 7,4462\%, namely the yield on the Obligation of Bank Panin III Year 2019 (PNBN19), while the lowest yield was 7,9304\%, namely the yield on Obligation of XIII Perum Pegadaian Year 2019 Series A1 (PPGD19A1).

\section{BI Rate}

The BI rate is the interest rate set by Bank Indonesia. This variable is measured by recording the Bank Indonesia interest rate (BI rate) data at the end of the year sourced from Bank Indonesia. Following are the descriptive statistics of the BI rate during the $2017-2020$ period:

\section{Tabel 4 Descriptive Statistics of BI rate}

Descriptive Statistics

\begin{tabular}{|c|c|c|c|c|c|}
\hline & $\mathrm{N}$ & Minimum & Maximum & Mean & Std. Deviation \\
\hline BI rate & 100 & 5.85 & 6.60 & 6.1975 & .32740 \\
Valid N (listwise) & 100 & & & & \\
\hline
\end{tabular}

Source: Processed data

Based on table 4 , the results of data processing with a total of 100 observations from 25 samples of the Obligation of corporations during the four year observation period from 2017-2020 can be seen that the lowest value of the BI rate is $5.85 \%$ which occurred in 2020, while The highest BI rate was 6.60\% which occurred in 2017 and 2018. The average (mean) BI rate was $6.1975 \%$, and the standard deviation value was 0.32740 . 


\section{Exchange Rate}

The currency is the currency price of a country that in another country's currency is indicated or valued. The exchange rate in this study is the moderate Rupiah/US Dollars rate during the observation period at the end of the year. In the following, Rupiah/USD exchange rate descriptive stats are as follows during the period 2017-2020:

\section{Table 5 Descriptive Statistics of Rupiah/USD Exchange Rates}

Descriptive Statistics

\begin{tabular}{|l|c|c|c|c|c|}
\hline & $\mathrm{N}$ & Minimum & Maximum & Mean & Std. Deviation \\
\hline Exchange rate Rp/USD & 100 & 8891 & 9770 & 9382.35 & 282.922 \\
Valid N (listwise) & 100 & & & & \\
\hline
\end{tabular}

Source: Processed data

Based on table 5, the results of data processing with a total of 100 observations from 25 samples of Obligation of corporations during the four years observation period from 2017-2021 can be seen that the average (mean) exchange rate of IDR / USD during the observation period is IDR 9,382. - per USD. The lowest exchange rate of IDR / USD was IDR 8,891 per USD, which occurred in 2018, while the highest exchange rate of IDR / USD was IDR 9,770 per USD that occurred in 2020. The standard deviation value was 282,922 .

\section{Obligation Rating}

The Obligation rating shows an overview of the condition of the Obligation. Suppose the Obligation of the corporation issuing company has a high rating. In that case, it indicates the shape of the issuer's Obligation is good, and the risk level of default is low, and vice versa. In this study, using the Obligation of rating data sourced from PT. Petfinder. Following are the descriptive statistics for the Obligation of rank during the 2017-2020 observation period are as follows:

\section{Table 6 Obligation Rating Descriptive Statistics}

Descriptive Statistics

\begin{tabular}{|l|c|c|c|c|c|}
\hline & $\mathrm{N}$ & Minimum & Maximum & Mean & Std. Deviation \\
\hline Obligation Rating & 100 & 3 & 7 & 5.02 & 1.241 \\
Valid N (listwise) & 100 & & & & \\
\hline
\end{tabular}

Source: Processed data

Based on table 6, data processing results with 100 observations from 25 samples of Obligation of corporations during the four-year observation period from 2017-2020 can be seen that the average value of the Obligation of rating during the observation period is 5.02. The standard deviation value is 1.241 . The lowest value of the Obligation of rating is 3 (id AA scale value), while the highest value of the Obligation rating is 7 (idAA + scale value). 


\section{Coefficient of Determination}

The determination coefficient illustrates how much the independent variable, i.e. the rate, exchange rate and the obligation of rating used in the model of regression, can influence, i.e. the output of the obligation. The value of the Adjusted $\mathrm{R}$ Square shows the determination coefficient.

\section{Table 7 Coefficient of Determination}

\begin{tabular}{|c|c|c|c|c|}
\hline \multirow{2}{*}{ Model } & \multicolumn{5}{|c|}{ Model Summary } \\
\cline { 2 - 5 } & $\mathrm{R}$ & R Square & Adjusted R Square & Std. The error of the Estimate \\
\hline 1 & $.860^{\mathrm{a}}$ & .733 & .724 & .9561948 \\
\hline
\end{tabular}

a. Predictors: (Constant), Obligation Rating, Exchange Rate of IDR/USD, BI Rate

b. Dependent variable: Yield

Source: Processed Data

On the basis of Table 7 , the value of the adjusted $r$ square or the determination coefficient is 0.724 , which means that the percentage contribution of the variable effect of the $\mathrm{BI}$ rate and the exchange rate is $72.4 \%$. The remaining $28.6 \%$ are influenced by variables compared to other variables. This study did not include other independent variables.

\section{Multiple Linear Regression Analysis}

This analysis aims to determine the extent of the influence of the independent variables on the dependent variable. In this study, the dependent variable is yield, while the independent variables are: BI rate, exchange rate, and Obligation rating.

\section{Table 8 Multiple Linear Regression Analysis}

Coefficients

\begin{tabular}{|c|c|c|c|c|c|c|}
\hline & \multirow[t]{2}{*}{ Model } & \multicolumn{2}{|c|}{$\begin{array}{c}\text { Unstandardized } \\
\text { Coefficients } \\
\end{array}$} & \multirow{2}{*}{$\begin{array}{c}\begin{array}{c}\text { Standardized } \\
\text { Coefficients }\end{array} \\
\text { Beta }\end{array}$} & \multirow[b]{2}{*}{$\mathrm{t}$} & \multirow[b]{2}{*}{ Sig. } \\
\hline & & B & Std. Error & & & \\
\hline \multirow[t]{4}{*}{1} & (Constant) & -42.343 & 5.425 & & -7.642 & .000 \\
\hline & BI Rate & 4.892 & .352 & .922 & 15.255 & .000 \\
\hline & Exchange Rate of IDR / USD & .003 & .000 & .364 & 5.599 & .000 \\
\hline & Obligation Rating & -.343 & .087 & -.207 & -3.782 & .000 \\
\hline
\end{tabular}

a. Dependent variable: Yield

\section{Source: Processed Data}

The interpretation of the equation is as follows:

1. Constant value $(\alpha)$ is -42.323 , which means the yield obligation will decrease to 42.323 where the $\mathrm{BI}$ (BI rate), exchange rate and rating obligation are constant (fixed).

2. The BI rate variable (BI rate) regression coefficient $(\beta 1)$ is positive; in other words, the 4,892 percent rate is increased by 4,892 percent when the interest rate (BI rate) is 1 percent. A positive coefficient value and a 0.000 significance 
level show the positive and significant yield impact of the BI interest rate (BI rate).

3. The exchange rate variable regression coefficient $(\beta 2)$ is good, namely 0.003 , indicating that the return increases by 0.003 if the currency of Rupiah increases by 1 unit (that means the rate of exchange rupiah is weakening against USD). The exchange rate has a negative and significant impact on the result based on these results and a significant level of 0,000.

4. The coefficient of regression $(\beta 3)$ of the rating variable obligation has a negative value of -0.343 indicating that the yield will be decreased by 0.343 each 1 unit increase of the rating obligation. A 0.000 level of negative coefficient value and significance indicate a negative and substantial impact on yield by the obligation of rating.

\section{Autocorrelation Test}

Autocorrelation test to test if there are autocorrelation problems in the regression model. The Durbin Watson test is used to test whether or not there is an autocorrelation problem. A model that does not have an autocorrelation is a good model of regression.

Table 9 Autocorrelation Test

\begin{tabular}{|c|c|c|c|c|c|}
\hline \multicolumn{2}{|c|}{ Model Summary } \\
\hline 1 & $\mathrm{R}$ & R Square & Adjusted R Square & $\begin{array}{c}\text { Std. Error of the } \\
\text { Estimate }\end{array}$ & Durbin-Watson \\
\hline
\end{tabular}

a. Predictors: (Constant), Peringkat Obligation of, Nilai Tukar Rp/USD, BI rate

b. Dependent Variable: yield

Source: Processed data

Based on table 9, the Durbin-Watson test value is obtained with a value of 2.276. The test criterion for no autocorrelation is $d u<d<(4-d u)$, where $d u$ is the upper limit value obtained from the DW table and the $\mathrm{d}$ value is the Durbin Watson value in the table processed by SPSS. By using a significance level of $5 \%$, the value of $\mathrm{du}=1.736(\mathrm{~N}=100, \mathrm{k}=3)$. Based on these criteria, $1.736<2.175<(4-1.736)$, so it can be concluded that there is no autocorrelation problem.

The BI interest rate (BI rate) has a positive and significant effect on the yield of the Obligation of corporations because it has a positive regression coefficient of 4.527 and has a substantial level of less than 0.05 , namely $0.000<0.05$. The positive direction of the coefficient shows that if there is an increase in the Bank Indonesia interest rate (BI rate), there will be an increase in the yield on bonds.

The data processing results show a positive regression coefficient of 0.002 and a significance level of less than 0.05 , i.e. $0.000<0.05$, respectively. The coefficient value indicates that if the currency of Rupiah increases, which means that the exchange rate of Rupiah depreciates (wanes) from the USD, the bond yield increases. 
These results show that the exchange rate affects the outcome negatively and significantly.

The Obligation of rating has a negative and significant effect on the yield of Obligation of companies issuing Obligation of corporations because it has a negative regression coefficient of -0.529 and has a substantial level of less than 0.05 , namely $0.005<0.05$. The negative coefficient direction shows that the higher the Obligation of rating owned by the Obligation of issuing company, the lower the yield of the Obligation.

\section{CONCLUSION}

Results of the previous debate and analysis suggest that the variable Bank Indonesia Interest Rate (BI rate) has a significant positive impact on corporate yield binding obligations. If the interest rate of the Bank of Indonesia (BI) increases, the return on investors' bonds will also increase. The variable exchange rate has an adverse and significant effect on the corporate yield bond. The obligation of the corporation rating variable has a negative and significant impact on the bonding worker of the bond issuing corporation if it weakens (depreciates) against USD. The higher the Obligation of rating owned by the Obligation of giving company, the lower the Obligation of yield received by investors.

\section{REFERENCES}

1. Eichengreen, B., \& Hausmann, R. (1999). Exchange rates and financial fragility (No. w7418). National bureau of economic research.

2. Ferguson, N., \& Schularick, M. (2007). 'Chimerica' and the global asset market boom. International Finance, 10(3), 215-239.

3. Fidora, M., Fratzscher, M., \& Thimann, C. (2007). Home bias in global bond and equity markets: the role of absolute exchange rate volatility. Journal of International Money and Finance, 26(4), 631-655.

4. Gadanecz, B., Miyajima, K., \& Shu, C. (2018). Emerging market local currency sovereign bond yields: The role of exchange rate risk. International Review of Economics \& Finance, 57, 371-401.

5. Gupta, J., Chevalier, A., \& Sayekt, F. (2001). The causality between interest rate, exchange rate and stock price in emerging markets: The case of the Jakarta stock exchange. In Fuzzy Sets in Management, Economics, and Marketing (pp. 145-163).

6. Hasanudin, H. (2021). The Effect of Inflation, Exchange, SBI Interest Rate and Dow Jones Index on JCI on IDX 2013-2018. Budapest International Research and Critics Institute (BIRCI-Journal): Humanities and Social Sciences, 4(2), 2063-2072.

7. Hasanudin, H., \& Awaloedin, D. T. (2020). Pengaruh Current Ratio, Debt To Equity Ratio Dan Net Profit Margin Terhadap Return Saham Pada Perusahaan Jasa Sub Sektor Telekomunikasi Yang Terdaftar Di Bei Periode 2012-2018. Jurnal Rekayasa Informasi, 9(1), 6-19. 
8. Hofmann, B., Shim, I., \& Shin, H. S. (2021). Emerging market economy exchange rates and local currency bond markets amid the Covid-19 pandemic. Available at SSRN 3761875.

9. Nurwulandari, A., \& Adnyana, I. (2019). Did Inter-Regional Trade Agreements Bring Mutual Benefits? An Empirical Scheme of Indonesian Commodity Exports in Asean-China Free Trade Area. International Journal of Financial Research, 10(6), 241-249.

10. Nurwulandari, A., Hasanudin, H., \& Melati, M. (2021). Market Reactions on Corporate Actions in Growing and Nongrowing Energy-Consuming Companies. International Journal of Energy Economics and Policy, 11(3), 290-295.

11. Obstfeld, M., Shambaugh, J. C., \& Taylor, A. M. (2005). The trilemma in history: tradeoffs among exchange rates, monetary policies, and capital mobility. Review of economics and statistics, 87(3), 423-438.

12. Saenong, Z., Adam, P., Wali, A. R., \& Millia, H. (2020). Symmetric and Asymmetric Effect of Crude Oil Prices and Exchange Rate on Bond Yields in Indonesia. International Journal of Energy Economics and Policy, 10(2), 95.

13. Wahyudi, S., \& Pangestuti, I. R. D. (2017). Managing The Pension Fund To Improve Portfolio Performance: An Empirical Study On Employer Pension Funds In Indonesia.

14. Wahyudi, S., Hasanudin, H., \& Pangestutia, I. (2020). Asset allocation and strategies on investment portfolio performance: A study on implementing employee pension fund in Indonesia. Accounting, 6(5), 839-850.

15. Yusuf, A., \& Prasetyo, A. D. (2019). The effect of inflation, US bond yield, and exchange rate on Indonesia bond yield. Jurnal Perspektif Pembiayaan Dan Pembangunan Daerah, 6(6), 649-656. 